\title{
COMPUTER-AIDED OPTIMISATION OF ELECTRONIC CIRCUIT LAYOUT
}

\author{
Abas Wisam Mahdi Abas, \\ South Russian State Polytechnic University \\ (Novocherkassk Polytechnic Institute), \\ Novocherkassk, Russia, \\ abas.wisam.82@mail.ru
}

\author{
DOI: |0.36724/2072-8735-202|-|5-9-64-7| \\ Manuscript received 30 June 2021; \\ Accepted 26 August 2021 \\ Keywords: electrical circuit, placement constraints, \\ topological parameters, metric parameters, switching field, \\ optimization criteria and methods
}

\begin{abstract}
The problem of optimal placement of elements of electrical and electronic circuits is considered. The minimum weighted length of the connections is selected as the criterion. The scheme is defined by a matrix of connections. We consider a fixed set of element positions and a distance matrix based on an orthogonal metric. This problem is a variant of the general mathematical model, called the quadratic assignment problem. The geometric limitation of the problem is that no more than one element is placed in one cell. Combinatorial analogs of the Gauss-Seidel method, the genetic algorithm, and the corresponding hybrid methods for solving the quadratic assignment problem with optimal placement of electronic equipment elements are developed and implemented on a computer. A series of computational experiments was conducted, which showed satisfactory computational qualities of the proposed methods. The proposed computational method, which is a combinatorial analog of the method of coordinate descent and one of the variants of the general approach based on paired permutations, is characterized by the best computational qualities among the methods studied in the article. According to well-known studies, the genetic algorithm is obviously no worse than the Monte Carlo method. The research conducted in the article shows that the method of penalty functions in the problem of placement and for the case of a genetic algorithm is ineffective. Therefore, it is of interest to consider permutations without repetitions as individuals of the population. This circumstance is taken into account at the stages of selection and mutation: at these stages, the standard calculations according to the genetic algorithm are supplemented by the procedure of paired rearrangements of genes in the chromosome. The article provides a detailed description of the program for the implementation of the genetic method on a computer.
\end{abstract}

Information about author:

Abas Wisam Mahdi Abas, Post-graduate student of the South Russian State Polytechnic University (Novocherkassk Polytechnic Institute), Department of Applied Mathematics, Novocherkassk, Russia

Для цитирования:

Абас Висам Махди Абас Компьютерная оптимизация размещения элементов электронных цепей // Т-Сотm: Телекоммуникации и транспорт. 202I. Том I5. №9. С. 64-7I.

For citation:

Abas Wisam Mahdi Abas (202I) Computer-aided optimisation of electronic circuit layout. T-Comm, vol. I5, no.9, pp. 64-7I. (in Russian) 


\section{Introduction. Problem statement}

The task of optimal placement of electrical and electronic circuit elements and the tracing of their connections is one of the topical issues in the design of radio equipment [1-13]. When solving this problem, various criteria and constraints are applied [1]. As a result of calculation the coordinates of arrangement of separate elements of circuit on a switching field (SF) and topological characteristics of connections of their terminals are found. At structurally identical elements positions for their installation on controls are fixed, located in nodes of a rectangular grid and can be described by the following system of parameters: $n_{x}, n_{y}, h_{x}, h_{y}$, where $-n_{x}$ number of positions in a horizontal row; $n_{y}$ - number of positions in a vertical row; $h_{x}$ - horizontal step between positions; $h_{y}$ - vertical step between positions. The criterion in most cases is the minimum weighted length criterion (MWL) of connections.

Given elements $e_{1}, \ldots, e_{n}$, for each pair of elements weights $r_{i j}(i, j=1, \ldots, n)$, defining "degree of connection" of these elements and forming a matrix of connections $R=\left\{r_{i j}\right\}_{i, j=1, \ldots, n}$ are given. There is a set of positions for placing the elements $p_{1}, \ldots, p_{m}(m \geq n)$. Without loss of generality we will assume that $m=n$. Let us define distances between $d_{i j}(i, j=1, \ldots, n)$ pairs of positions that define a symmetric matrix $D=\left\{d_{i j}\right\}_{i, j=1, \ldots, n}$ with zero principal diagonal $d_{i i}=0(i=1, \ldots, n)$. An orthogonal metric is used to calculate the elements of matrix $D$.

Arbitrary placement of elements in positions is some permutation $p=\left(p_{1}, \ldots, p_{n}\right)$ of , where $p_{i}$ specifies the position number assigned to the $i$-th element. Thus, there is a total number of different $n$ ! placement variants for the elements. Attempts to find an optimal variant by a brute force search are unsuccessful even for small values of $n$ : $16 !=20922789888000=1013,32 \ldots$. $25 !=15511210043330985984000000=10^{25,19 \ldots}$

An example of a control is given in Figure 1 and 2. The length of the connections between the elements and $e_{i} e_{j}$ is evaluated by the value of $L_{i j}=r_{i j} d_{p(i) p(j)}(i, j=1, \ldots, n)$.

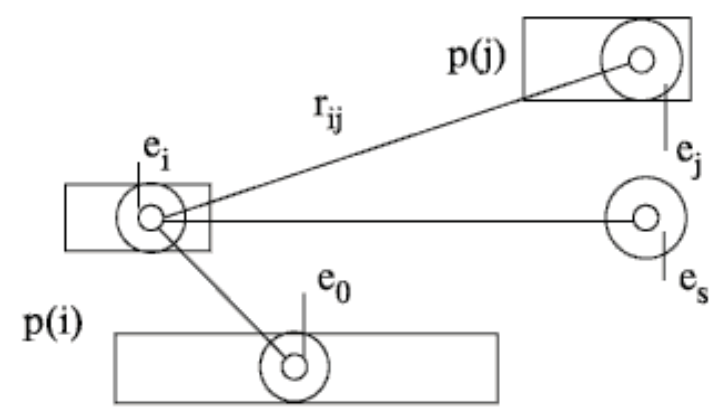

Figure 1. Representation of the switching field

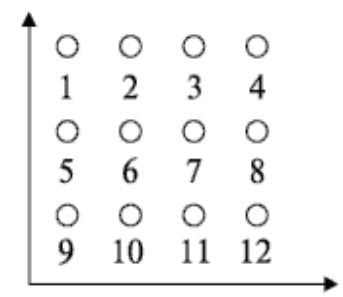

Figure 2. Fixed set of 12 positions

Denote by the set $E_{S}$ of all fixed elements, including the elemen $e_{0}$, then the total weighted length of connections of the element $e_{i}$ with elements from $E_{S}$ is estimated by the formula:

$$
a_{i p(i)}=\sum_{s \in E_{s}} r_{i s} d_{p(i) s}(i=1, \ldots, n),
$$

where $d_{p(i) s}$ is the distance between $e_{i}$ the element in position $p_{i}$, and the element $e_{s}$.

Given the symmetry of the R and D matrices, let us write down an expression for the total weighted length of the connections for an arbitrary placement:

$$
F(p)=\frac{1}{2} \sum_{i=1}^{n} \sum_{j=1}^{n} r_{i j} d_{p(i) p(j)}+\sum_{i=1}^{n} a_{i p(i)} .
$$

For an orthogonal metric, the problem of placement according to the MSVD criterion of connections is to minimise the functional:

$$
\begin{aligned}
& F(p)=\frac{1}{2} \sum_{i=1}^{n} \sum_{j=1}^{n} r_{i j}\left(\left|x_{i}-x_{j}\right|+\left|y_{i}-y_{j}\right|\right)+ \\
& +\sum_{i=1}^{n} \sum_{s \in E_{s}} r_{i s}\left(\left|x_{i}-x_{s}^{0}\right|+\left|y_{i}-y_{s}^{0}\right|\right)
\end{aligned}
$$

on the set of permutations of $P$ connections. This problem is a variant of a general mathematical model called the quadratic assignment problem [1, 6-8].

Geometric restriction - no more than one element can be placed in one cell, i.e.

$$
\begin{aligned}
& \min _{i, j=1, \ldots n} \max \left\{\frac{\left|x_{i}-x_{j}\right|}{h_{x}}, \frac{\left|y_{i}-y_{j}\right|}{h_{y}}\right\} \geq 1, \\
& \min _{i=1, \ldots n} \max \left\{\frac{\left|x_{i}-x_{s}^{0}\right|}{h_{x}}, \frac{\left|y_{i}-y_{s}^{0}\right|}{h_{y}}\right\} \geq 1,
\end{aligned}
$$

$$
x_{i}=I_{i} h_{x}, y_{i}=J_{i} h_{y}, i=1, \ldots, n ; I_{i} \in\{1, \ldots, n\}, J_{i} \in\{1, \ldots, n\}
$$




\section{Combinatorial analogues of the Gauss-Seidel method in the placement problem}

\subsection{Classic variant}

We will solve the integer optimization problem with the target function $F(x)$, where $x$ is the vector of optimized placement parameters, namely, permutation without repetitions of position numbers of $n$ elements. The coordinates of cells for element placement can be calculated through the position number. Such an approach is economical for the reason that geometric constraints are automatically taken into account.

Experience shows that if we solve the problem in the usual way for the target function with geometric constraints taken into account by the penalty function method, the laboriousness increases quite significantly. The problem gets "bored" in one place in the penalty area which has a complex form. Escaping from the penalized area is very difficult, as a consequence, all considered traditional optimization methods for continuous argument functions fail. If we consider only the space of permutations without repetitions, there is no need for penalty functions. But when using conventional variants of the optimization methods, there is a high probability of exceeding the boundaries of the considered permissible domain.

This can be avoided by some modification of standard optimization methods. The problem is most simply solved for the Gauss-Seidel (co-ordinate descent) method. In the classical variant of this method each coordinate is stepped in turn in order to find the smaller value of the target function. Here you can choose between searching for a local minimum for each coordinate with a certain accuracy, e.g. you can limit yourself to one step towards decreasing the value of the function, or you can search for the exact value of the local minimum coordinate. The first approach seems pragmatic for a number of reasons, first of all due to simplification of the algorithm, especially considering the integer nature of the arguments.

At the first step of this optimization procedure, as a rule, there is an overrun of the permissible area. In the modified combinatorial variant of the method after such a step the permutation is corrected: the argument whose value coincided with the new value of the varied coordinate is found. The value of this argument is replaced by the original value (before the optimization step) of the varied coordinate. As a result, there is a return to the permutation space without repetitions (repetition of position number values is eliminated). Thus, in the combinatorial variant of the co-ordinate descent method two coordinates are changed simultaneously at one calculation step (instead of one as in the usual variant) - the usual trial step is made along one of the coordinates, and along the other one correction, return to the acceptable area is made.

Then the value of the target function at the found point is calculated and compared to the previously achieved value. If there is improvement of the value, the found point becomes a new starting point. Otherwise a step on another coordinate is made with simultaneous correction of the vector of item numbers (return to the allowable area). It's clear that the considered complication of the algorithm of the co-ordinate descent method can lead to some decrease in its usual high efficiency. Nevertheless, the experience of applying the combinatorial variant of the method in solving the EVA placement problem has shown its significant advantages over other known methods, such as the genetic algorithm and the penalty function method.

As a rule, this method allows to find a local minimum. To find the global optimum, the so-called multistart method is used. The new starting point is chosen most simply by Monte Carlo method with equal probability in the whole admissible region. It is possible to wander similarly to the annealing method based on some transition probability $[10,11]$. Start selection can be done in the immediate vicinity of the achieved local minimum. It is advisable to apply criteria for selecting starting points that are effective for the particular problem.

\subsection{A randomised combinatorial analogue of the "fast variable" method}

The classical procedure of the Gauss-Seidel method for the problem in question may not be rational for the following reason. At each computational step, local optimization is performed on each of the $n$ variables of the target functions, while these computations are relatively expensive. There is a randomised variant of the Gauss-Seidel method, in which the variables for which local optimisation is carried out are chosen randomly and equally likely. But on average, the computational complexity here is of a similar order of magnitude.

Therefore considered variants of the Gauss-Seidel method in this respect lose to the genetic algorithm which requires the number of calculations of the target function at each step of the order of number of individuals in one generation $\mathrm{m}$. Similar is the case with the swarm method, for which $N$ target functions equal to the dimensionality of the swarm are computed at each step. An improvement of the procedure of the Gauss-Seidel method is achieved in its variant, called the fast variable method, which is chosen from the condition of the maximum modulus of derivatives on coordinates from the target function.

However, this also requires $n$ estimates of the derivatives. A favorable circumstance is that in the quadratic assignment problem the fast variable can be found from the values of the relationship matrix. Such variables correspond to the elements that have the largest number of links. That is, the estimated criterion for the fast variable is a value equal to the matrix norm for the relationship matrix $R$, namely $\max _{i=1, \ldots, n} \sum_{j=1}^{n} r_{i j}$. However, this criterion is, as noted, an estimator; for this and other reasons, improving the computational qualities of the method is achieved through randomization. In this case the choice of coordinates for local optimization is random, but the probability of variable selection is directly proportional to the row sum of the link matrix $R$, namely $\sum_{j=1}^{n} r_{i j}, i=1, \ldots, n$, equal to the number of links of the element with the remaining elements of the chain.

\subsection{Examples of calculations.}

\subsubsection{An analogue of the classical Gauss-Seidel method}

The connection matrix is given analytically in the form of

$$
r_{i j}=i+j(i \neq j), r_{i i}=0,(i, j=1, \ldots, n) .
$$


Step of a cell, number of steps by coordinates and total number of cells and elements: $h=1 ; n_{0}=6 ; n=36$. At the beginning the initial approximation was searched by Monte Carlo method (10 000 iterations), after that the local optimum was calculated by combinatorial method of co-ordinate descent (a limit of 100 iterations was set). The initial value of the step by coordinate was equal to $n$, further on each iteration it was reduced by 1 until the minimum possible value was equal to 1 .

The initial approximation turned out to be $x_{0}=(36,12,6,1,35,19,5,32,31,26,29,34,8,16,28$, $33,13,24,10,2,18,4,27,21,22,15,7,25,11,3,17,9,23,14,20,30)$, the corresponding value of the target function $f_{\text {min } \_0}=177648$. After calculations by combinatorial descent method, the solution has the form: $\quad x_{1}=\quad(36,1,6,31,35,2,12,32,5,7,25,4,30,33,34,13,19$, $24,3,18,26,29,8,28,11,27,9,10,23,20,17,14,16,21,15,22)$, local optimum $f_{\min }=171168$ (found after 1 iteration, after 2-3 iterations the smallest value found with more iterations is 171120).

Example of calculations without finding a refined initial approximation. After the first iteration by Monte Carlo method: $f_{\text {min_0 }}=185400$;

$x_{0}=(6,30,19,3,12,33,2,10,9,20,18,25,7,26,13,4,24,27,16,23,17$ ,8,28,21,5,34,29,11,22,36,15,1,35,31,32,14). The solution found further by a modified method of descending is much better: $f_{\text {min }}=171192$;

$x^{(1)}=(6,1,36,31,35,12,5,25,30,2,32,33,7,3,34,18,24,4,19,29,13$ ,8,11,9,26,28,10,20,14,17,27,23,16,15,21,22).

\subsubsection{Fast Variable Method}

\section{Start point}

$\{36,12,6,1,35,19,5,32,31,26,29,34,8,16,28,33,13,24,10,2,18,4,27$ ,21,22, 15,7,25,11,3,17,9,23,14,20,30). After $k=46$ iterations, $f_{\min }=171120$.

In the classical variant after the first iteration $f_{\min }=171168$, after 2 iterations $f_{\min }=171120$ (no further improvement with more iterations), but the ratio of computational cost per step in this variant is 1 to 36 compared to the fast variable method.

It is found that in the presence of elements with a very large number of links, the fast variable method can significantly improve accuracy in the first few iterations. But for further refinement it is reasonable to apply the random variable method or the classical version of the combinatorial Gauss-Seidel method.

\section{A method for solving the placement problem based on a genetic algorithm and pairwise permutations}

The genetic optimization algorithm is an example of the bionic approach $[9,13]$. It consists of the following.

1. In the first step, an initial population is set up with a defined population size.

2. In the second step, survival factors are calculated according to the target function, and their sum is equal to one. Sometimes relative error estimates and similar criteria are applied.

3. statistical generation of a given number of breeding pairs is carried out. The probability of an individual being paired is determined by the survival rate (value of the value function).

4. The selected pairs are crossed over. The vectors of the independent variables are divided into two parts, which the members of the pair exchange. As a result, offspring with mixed vectors, form a new population.
5. If the characteristics of the offspring are poor, it is rational to use a mutation based on randomisation.

6. S ection of offspring enables selection of individuals with the best survival properties.

7. I the solution found needs to be improved, then proceed to step 2.

According to research, the genetic algorithm converges as well as the Monte Carlo method. Other stochastic optimization algorithms are also known [10,11].

This study shows that the penalty function method in the placement problem and for the case of the genetic algorithm is inefficient. Therefore it is of interest to consider permutations without repetitions as individuals of the population. This circumstance is taken into account at the stages of selection and mutation: at these stages, the standard calculations according to the genetic algorithm are supplemented by the procedure of pairwise permutations of genes in the chromosome.

A description of the software to implement the method described:

First, the dimensionality of the problem and the relationship matrix of the elements $r[i, j]$ are specified.

Then using a given number of iterations, the Monte Carlo method finds $m$ different permutations without repetitions of the numbers $1, \ldots, n$-the initial approximation to the solution of the problem, or the first generation of $m$ individuals.

The following calculation steps are iterated according to the genetic algorithm method with correction according to the pairwise permutation method (this ensures that the penalty function is always equal to zero, i.e. there is no overstepping of the permissible area):

1) Survival rates for each individual and the corresponding probabilities of participation in the cross are calculated.

2) Monte Carlo draw of the numbers of $m$ pairs of individuals to cross. The probabilities of participating in the crosses are proportional to the survival rate of the individual.

3) The inbreeding procedure results in $2 m$ offspring. Cross-breeding is carried out according to the following rule. The first offspring consists of the head part of the second parent's chromosome of length $k$ elements. The remaining $n-k$ genes form the tail of the first offspring's chromosome, and are taken from the first parent. The second offspring is obtained in a similar way, but with mirror symmetry: it consists of the head part of the first parent's chromosome with length of $k$ genes. The remaining $n-k$ genes form the tail of the second offspring's chromosome and are taken from the second parent.

4) The chromosomes of $2 \mathrm{~m}$ descendants obtained by the usual crossing procedure in step 3 are modified according to the rules of the pairwise permutation method to return the corresponding integer sets of numbers to the admissible set of permutations without repetitions of the first $\mathrm{n}$ natural numbers. In this case, $k$ first genes of descendant are considered one by one, for each one the matching gene of its chromosome is found. To eliminate duplication of genes, instead of the found copy of the head gene the corresponding gene from the head of its parent's chromosome is substituted. This chromosome modification is essentially a kind of mutation of the offspring obtained in step 3.

In the PascalABC programming system, steps 3 and 4 are carried out as follows. 3 and 4 are carried out in the following program block: 
for $\mathrm{i}:=1$ to $\mathrm{m}$ do

begin i1:=num[i,1]; i2:=num[i,2];

for $\mathrm{j}:=1$ to $n$ do gen $1[\mathrm{i}, \mathrm{j}]:=$ gen $0[\mathrm{i} 1, \mathrm{j}]$;

for $\mathrm{j}:=1$ to $\mathrm{k}$ do begin $\mathrm{g}:=$ gen $1[\mathrm{i}, \mathrm{j}]$; gen $1[\mathrm{i}, \mathrm{j}]:=$ gen0[i2,j];

j0[j]:=e_num_(i,j,gen1[i,j],gen1,res[j]);

if res[j] then gen $1[\mathrm{i}, \mathrm{j} 0[\mathrm{j}]]:=\mathrm{g}$; end;

for $\mathrm{j}:=1$ to $n$ do gen2[i,j]:=gen0[i2,j];

for $\mathrm{j}:=1$ to $\mathrm{k}$ do begin $\mathrm{g}:=$ gen2[i,j]; gen2[i,j]:=gen0[i1,j];

j0[j]:=e_num_(i,j,gen2[i,j],gen2,res[j]);

if res[j] then gen $2[\mathrm{i}, \mathrm{j} 0[\mathrm{j}]]$ :=g; end; end;

Here i1, i2 are numbers of individuals participating in the interbreeding (the numbers are played out randomly according to item 2 ), gen $0[i, j]$ is the matrix of the parent population, the rows of which correspond to the individuals (chromosomes), gen $1[i, j]$, gen2 $[\mathrm{i}, \mathrm{j}]$ are matrices of descendant chromosomes.

5) The selection is carried out according to the survival criterion among two generations from a pooled population of $3 \mathrm{~m}$ individuals. The selection includes $m$ individuals from the original population and all $2 m$ children. The $m$ best individuals are retained.

for $\mathrm{i}:=1$ to $\mathrm{m}$ do for $\mathrm{j}:=1$ to $\mathrm{n}$ do

begin gen $3[\mathrm{i}, \mathrm{j}]$ :=gen0[i,j]; gen3[i+m,j]:=gen1[i,j];

gen $3[\mathrm{i}+2 * \mathrm{~m}, \mathrm{j}]$ :=gen $2[\mathrm{i}, \mathrm{j}]$; end;

ord_( $3^{*} \mathrm{~m}$,gen $\left.3, \mathrm{i} 0\right)$; for $\mathrm{i}:=1$ to $\mathrm{m}$ do for $\mathrm{j}:=1$ to $\mathrm{n}$ do gen $0[\mathrm{i}, \mathrm{j}]$ :=gen3[i0[i],j];

6) Preventing duplication of individuals in a population. When a duplicate is found, a second copy of the repeating individual is replaced with an individual obtained by the Monte Carlo method.

for i1 $:=1$ to $m$ do for i2 $:=\mathrm{i} 1+1$ to $m$ do begin $b:=$ true; for $\mathrm{j}:=$ 1 to $n$ do if gen $0[i 1, j]<>$ gen $0[i 2, j]$ then $b:=$ false; if $b$ then begin p3(x); for $\mathrm{j}:=1$ to $n$ do gen $0[\mathrm{i} 2, \mathrm{j}]:=\mathrm{x}[\mathrm{j}]$; end; end;

7) Mutation is carried out - the worst individual (always having number $\mathrm{m}$ after a given number of iterations (generations)) is replaced by a random individual from a valid set using the Monte Carlo method.

if iter $\bmod 2=0$ then begin $\mathrm{p} 3(\mathrm{x})$; for $\mathrm{j}:=1$ to $\mathrm{n}$ do gen $0[\mathrm{~m}, \mathrm{j}]:=\mathrm{x}[\mathrm{j}]$; end;

The stopping criterion is the limiting number of iterations (generations). Calculation of the target function:

function $\mathrm{f}(\mathrm{x}$ : Vector) : integer; var s,i,j : integer; xx,yy :

Vector0;

begin

for $\mathrm{i}:=1$ to $\mathrm{n}$ do begin $\mathrm{xx}[\mathrm{i}]:=\mathrm{h} *(\operatorname{trunc}((\mathrm{x}[\mathrm{i}]-1) / \mathrm{n} 0)+1)$;

yy[i]:=h*(x[i]-n0*trunc $((x[\mathrm{i}]-1) / \mathrm{n} 0))$; end;

$\mathrm{s}:=0$; for $\mathrm{i}:=1$ to $\mathrm{n}$ do for $\mathrm{j}:=1$ to $n$ do if $\mathrm{i}<>\mathrm{j}$ then

$\mathrm{s}:=\mathrm{s}+\mathrm{r}[\mathrm{i}, \mathrm{j}] * \mathrm{~d}(\mathrm{i}, \mathrm{j}, \mathrm{xx}, \mathrm{yy}) ; \mathrm{f}:=\mathrm{s}$; end; $\{\mathrm{f}\}$

Calculation of the survival vector of individuals of the same generation and the probabilities of participating in a cross:

procedure p1(gen : Matrix; var v,z : Vector1; m : integer);

var s : real; i,j : integer; $x$ : Vector; $p$ : Vector1;

begin

for $\mathrm{i}:=1$ to $\mathrm{m}$ do begin for $\mathrm{j}:=1$ to $\mathrm{n}$ do $\mathrm{x}[\mathrm{j}]:=\operatorname{gen}[\mathrm{i}, \mathrm{j}]$;

$\mathrm{v}[\mathrm{i}]:=\operatorname{abs}(\mathrm{f}(\mathrm{x}))$; end;

$\mathrm{s}:=0$; for $\mathrm{i}:=1$ to $\mathrm{m}$ do $\mathrm{s}:=\mathrm{s}+1 / \mathrm{v}[\mathrm{i}]$; for $\mathrm{i}:=1$ to $\mathrm{m}$ do

$\mathrm{p}[\mathrm{i}]:=1 / \mathrm{v}[\mathrm{i}] / \mathrm{s} ; \mathrm{z}[0]:=0$;

for $\mathrm{i}:=1$ to $\mathrm{m}$ do $\mathrm{z}[\mathrm{i}]:=\mathrm{z}[\mathrm{i}-1]+\mathrm{p}[\mathrm{i}]$;

end; $\{\mathrm{p} 1\}$
Calculating the random number of an individual to participate in a cross:

function num_(m : integer; $\mathrm{z}$ : Vector1) : integer; var v : real; j : integer; begin $\mathrm{v}:=$ random; for $\mathrm{j}:=1$ to $\mathrm{m}$ do if $(\mathrm{z}[\mathrm{j}-1]<=\mathrm{v})$ and $(\mathrm{v}<\mathrm{z}[\mathrm{j}])$ then num_:=j; end; $\{$ num_\}

Arrangement of individuals of the two generations according to their value function:

procedure ord_(m : integer; gen : Matrix1; var i0: Vector2); var v,vmin : real; i,j,k : integer; b : boolean;

begin for $\mathrm{i}:=1$ to $\mathrm{m}$ do begin vmin:=MaxInt; for $\mathrm{j}:=1$ to $\mathrm{m}$ do begin $b:=$ true; for $k:=1$ to $i-1$ do if $j=i 0[k]$ then $b:=$ false; if $b$ then begin $\{1\}$

$\mathrm{v}:=\mathrm{w} 3(\mathrm{j}, \mathrm{m}, \mathrm{gen})$; if $\mathrm{v}<\mathrm{vmin}$ then begin $\{2\}$ vmin:=v; i0[i]:=j; end; $\{2\}$ end; $\{1\}$ end; $\{j\}$ end; $\{i\}$ end; $\{$ ord_\}

Calculates the item number at a given position:

function e_num(p : 1...n; $x$ : Vector $): 1 . . n$; var i : integer; begin for $\mathrm{i}:=1$ to $\mathrm{n}$ do if $\mathrm{p}=\mathrm{x}[\mathrm{i}]$ then e_num :=i; end; $\left\{\mathrm{e} \_\right.$num element number at position $\mathrm{p}\}$

function e_num_(i,j,p : 1..n; gen : Matrix; var res : boolean) : 1..n; var $\mathrm{k}$ : integer; begin res:=false; for $\mathrm{k}:=1$ to $\mathrm{n}$ do if $\mathrm{k}<>\mathrm{j}$ then if $\mathrm{p}=$ gen[i,k] then begin $\mathrm{e}_{-}$num_ $:=\mathrm{k}$; res := true; end; end;

\{e_num_- number of element in p position for row in matrix gen

Calculating a random chromosome:

procedure p3(var x : Vector); label 1; var i,j : integer; b : boolean; begin for $\mathrm{i}:=1$ to $\mathrm{n}$ do begin 1 : $\mathrm{x}[\mathrm{i}]:=\operatorname{random}(\mathrm{n})+1$; $\mathrm{b}:=$ false; for $\mathrm{j}:=1$ to $\mathrm{i}-1$ do if $\mathrm{x}[\mathrm{i}]=\mathrm{x}[\mathrm{j}]$ then begin $\mathrm{b}:=$ true; break; end; if $\mathrm{b}$ then goto 1 ; end; end; $\{\mathrm{P} 2$ random permutation without repeats

\section{Example of calculations}

\subsection{Genetic algorithm}

The connection matrix is sparse and is given as $r_{i j}=1,|i-j|=1 ; r_{i j}=0,|i-j| \neq 1 ; i, j=1, \ldots, n$. Cell step, number of coordinate steps, total number of cells and elements, number of individuals in one population: $h=1 ; n_{0}=6 ; n=36 ; m=5$; Every two calculation steps a mutation was performed, the worst population member was replaced by a random one. The initial placement is shown in Fig. $3\left(x_{i}=i, i=1, \ldots, n\right)$. The corresponding value of the target function $f_{\min }=120$, with exact $f_{\text {inf }}=70$.

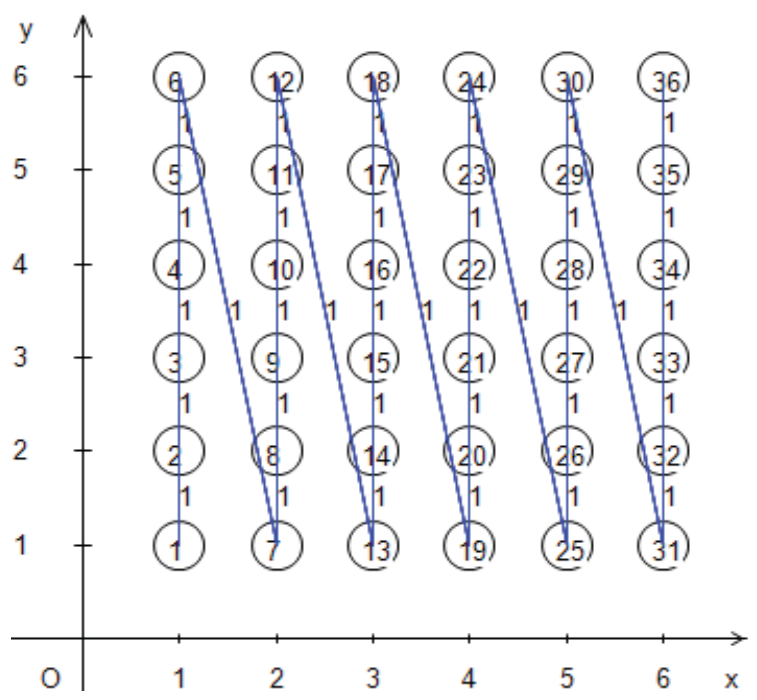

Figure 3. Genetic algorithm method. Initial placement 
The best approximate solution after 28790 iterations is $f_{\min }=76$ (it was not improved after 100,000 iterations either), see Figure 4.

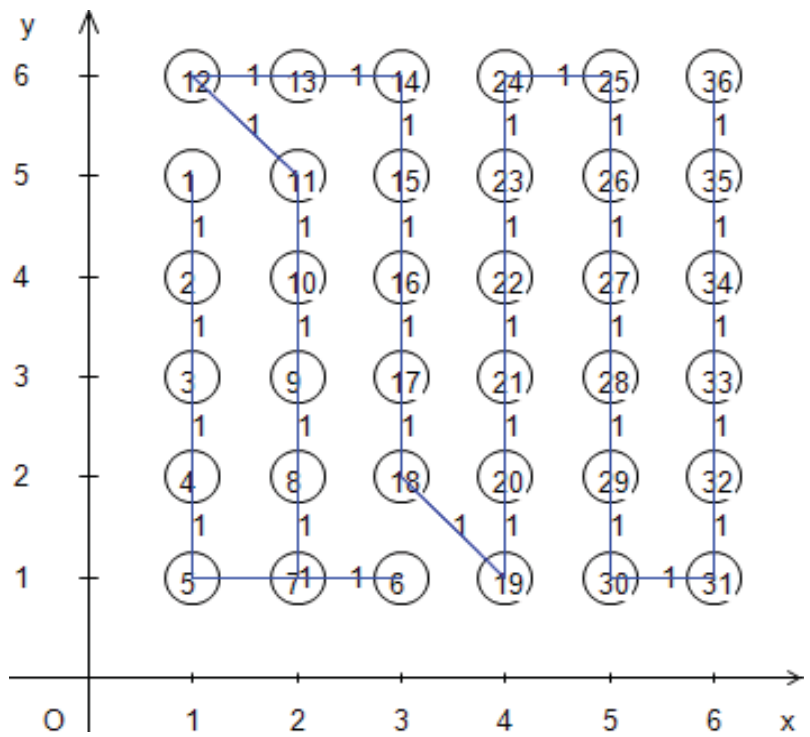

Figure 4. Genetic algorithm method. Locally optimal placement after 28790 iterations

\subsection{Hybrid method "genetic algorithm+combinator analog of the Gauss-Seidel method}

The initial condition is the same as in the previous point (Figure 3). The global optimum is reached after 59 iterations (see Figure 5 and table).

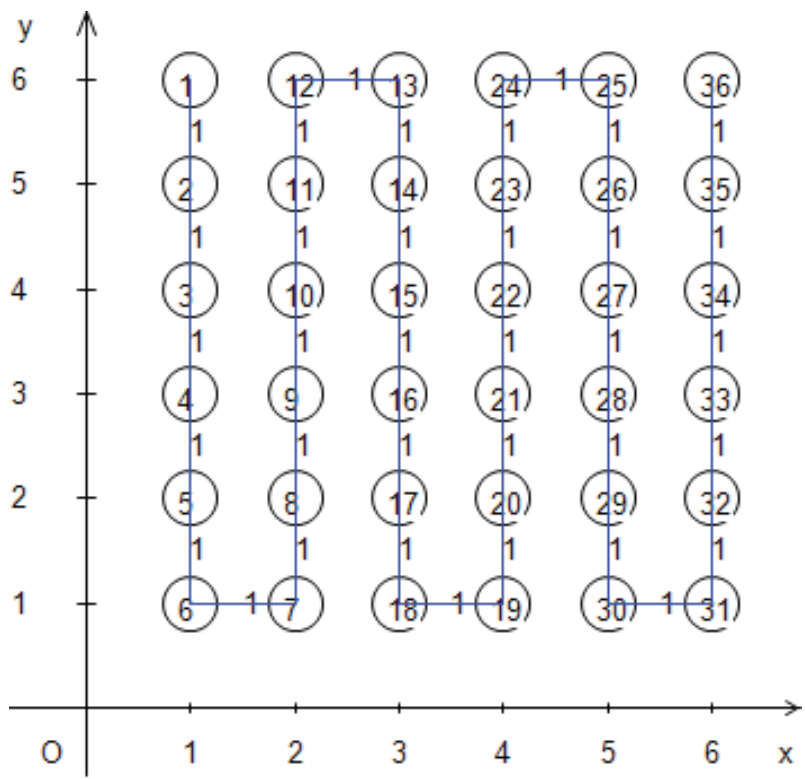

Figure 5. Hybrid method. Global optimum
Table

Calculation results

\begin{tabular}{|c|rrrrr|}
\hline Iteration number & \multicolumn{6}{|c|}{$\begin{array}{c}\text { The values of individuals } \\
\text { in the population }\end{array}$} \\
\hline 1 & 120 & 270 & 304 & 284 & 306 \\
\hline 3 & 112 & 214 & 260 & 136 & 242 \\
\hline 5 & 104 & 192 & 132 & 250 & 208 \\
\hline 9 & 96 & 102 & 112 & 112 & 208 \\
\hline 10 & 88 & 96 & 224 & 100 & 98 \\
\hline 11 & 84 & 88 & 224 & 96 & 214 \\
\hline 21 & 78 & 222 & 84 & 224 & 242 \\
\hline 28 & 74 & 78 & 240 & 78 & 80 \\
\hline 59 & 74 & 78 & 74 & 222 & 256 \\
\hline $59^{1}$ & 70 & 74 & 74 & 74 & 78 \\
\hline $59^{2}$ & 70 & 74 & 74 & 286 & 78 \\
\hline $59^{3}$ & 70 & 74 & 74 & 214 & 78 \\
\hline
\end{tabular}

${ }^{1}$ After crossbreeding and selection among the generations

${ }^{2}$ After mutation. ${ }^{3}$ After improvement by the Gauss-Seidel method

\subsection{Chains with multiple links between elements}

The initial placement of the 36 chain elements is shown in fig. 6. The number of linking elements is uniformly distributed randomly from 1 to 5 . The corresponding initial value of the target function $f_{\min }=324$, with exact $f_{\text {inf }}=208$.

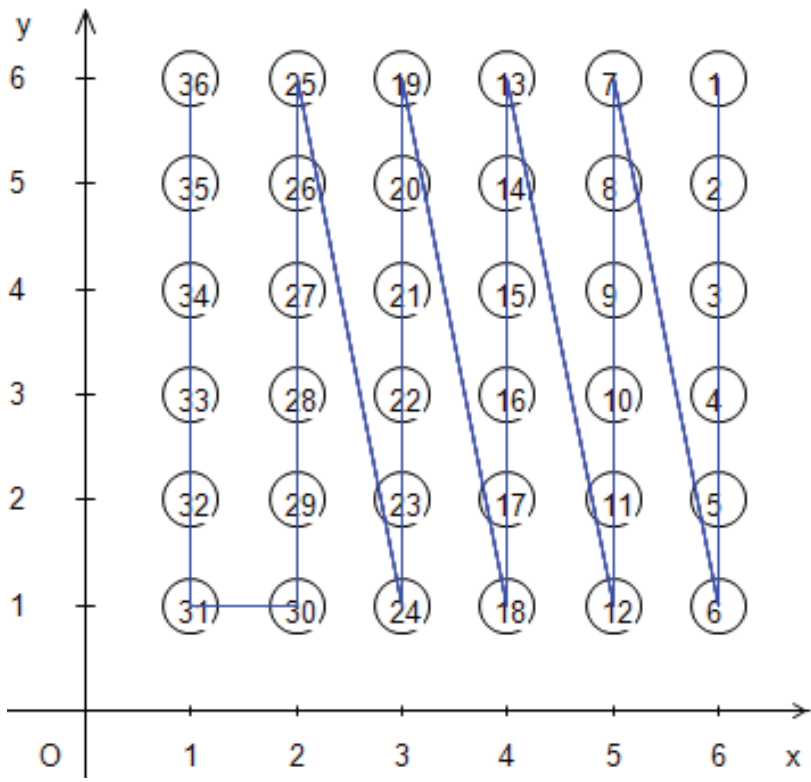

Figure 6. Hybrid method. Initial placement

The global optimum is reached at iteration 353 and is shown in Figure 7.

The computational process does not in all cases converge quickly to an exact solution. The local optimum shown in Figure 8 $\left(f_{\min }=244\right.$, with exact $\left.f_{\text {inf }}=226\right)$, was reached after 25,000 iterations. At each step, 1 mutation was performed. The remaining conditions are the same as in the previous paragraphs. 


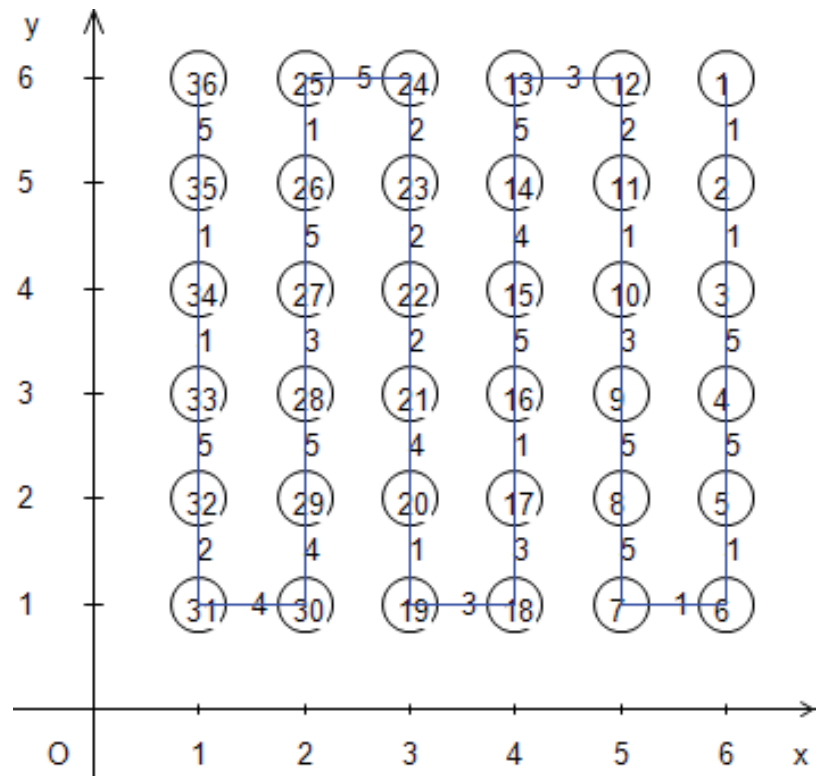

Figure 7. Hybrid method. Global optimum

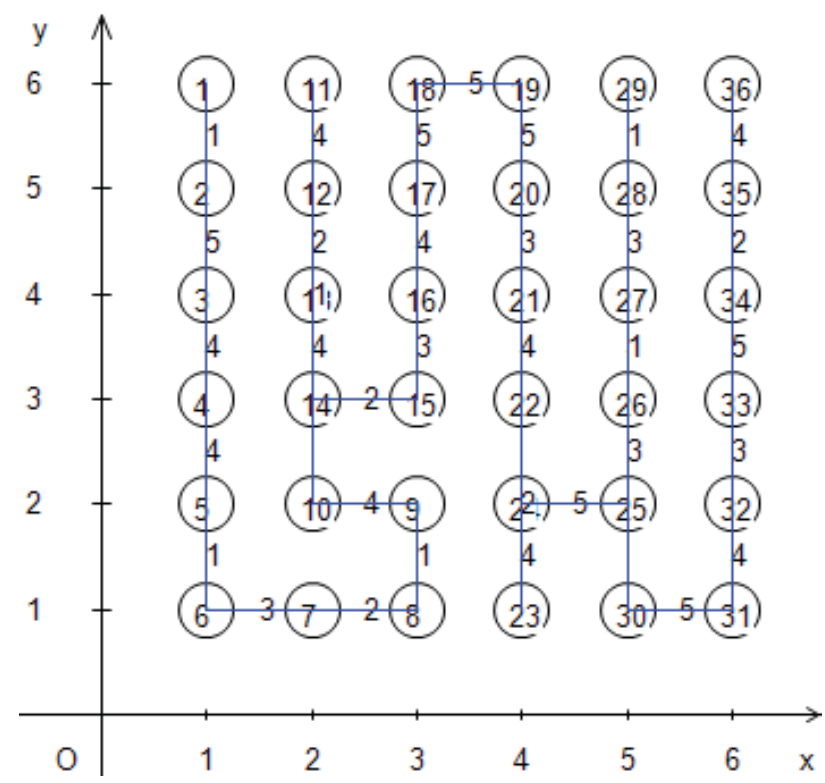

Figure 8. Hybrid method. Locally optimal placement

\section{Conclusions}

Combinatorial analogues of Gauss-Seidel method, genetic algorithm and hybrid methods for solving a quadratic problem of optimal electronic equipment allocation were developed and realised on computer. A series of computational experiments were carried out and showed satisfactory computational qualities of proposed variants of the methods.

\section{References}

1. Algorithms for placing elements [Electronic resource]. https://helpiks.org/8-12562.html (accessed: 03.04.2021).

2. N. P. Nikolov (1985). Placement of elements of electronic nodes by the method of multilevel decomposition and macromodeling and implementation on its basis of PPP for CAD REA. Diss.. Candidate of Technical Sciences, specialty 05.13.12. Lviv.

3. A. A. Gorbachev (1999). Methods and algorithms of spatial tracing of printed circuit boards. Diss. Candidate of Technical Sciences, specialty 05.13.12. Kaliningrad.

4. V. A. Selyutin (1983). Computer-aided design topology BIS. Moscow: Radio and communication. $112 \mathrm{p}$.

5. K. K. Morozov, V. Odinokov, V. M. Kureychik (1983). Automated design of electronic equipment. Moscow: Radio and communication. $278 \mathrm{p}$.

6. V. A. Martyushev (2005). Method of whips and bounds in quadratic task of appointments: Diss.... Cand. Fiz.-Mat. science: 01.01.09. Saint-Petersburg, $100 \mathrm{p}$.

7. G. S. Kolubetskis (1988). Generator of test problems of quadratic assignment with a known optimal solution. math. and Math. phys.

Vol. 28. No. 11, pp. 1740-1743.

8. A. D.Leushkin, E. A. Neymark (2020). Quadratic problem on the assignment. Review of methods, generation of test problems with a priori known optimum. Trudy NSTU named after R. E. Alekseev. No. 4 (131), pp. 26-35.

9. N. V. Starostin, N. V. Bykova (2017). Multilevel algorithm for solving the problem of architecture-dependent decomposition. Educational and methodical manual. Nizhny Novgorod: Nizhny Novgorod State University. 24 p.

10. S. A. Rashkovsky (2016). Solving problems of combinatorial optimization by the monte carlo method. Vol. 471. No. 4. P. 403-407.

11. S. A. Rashkovskiy (2016). Monte Carlo solution of combinatorial optimization problems. Doklady Mathematics. Vol. 94. No. 3, pp. 720-724.

12. B. S. Darkhovsky, A. Popkov, Yu. Popkov (2014). Batch iterations of Monte Carlo for solving problems of global optimization. Itis, 2014, issue 3, pp. 39-52.

13. A. A. Kulakov (2016). Development and research of algorithms for optimal placement of components VLSI three-dimensional integration. dissertations and abstracts on the Higher Attestation Commission of the Russian Federation 05.13.12, Candidate of Technical Sciences. 2016, Taganrog. P. 164. 


\section{КОМПЬЮТЕРНАЯ ОПТИМИЗАЦИЯ РАЗМЕЩЕНИЯ ЭЛЕМЕНТОВ ЭЛЕКТРОННЫХ ЦЕПЕЙ}

Абас Висам Махди Абас, Южно-Российский государственный политехнический университет (Новочеркасский политехнический институт), Новочеркасск, Россия, abas.wisam.82@mail.ru

\section{Аннотация}

Рассматривается задача оптимального размещения элементов электрических и электронных цепей. В качестве критерия выбран минимум взвешенной длины соединений. Схема задана матрицей соединений. Рассматривается фиксированный набор позиций элементов и матрица расстояний на основе ортогональной метрики. Данная задача является вариантом общей математической модели, получившей название задачи квадратичного назначения. Геометрическое ограничение задачи - в одной ячейке размещается не более одного элемента. Разработаны и реализованы на ЭВМ комбинаторные аналоги метода Гаусса-Зейделя, генетического алгоритма и соответствующие гибридные методы для решения задачи квадратичного назначения при оптимальном размещении элементов электронной аппаратуры. Проведена серия вычислительных экспериментов, которые показали удовлетворительные вычислительные качества предложенных вариантов методов. Предложенный вычислительный метод, являющийся комбинаторным аналогом метода покоординатного спуска и одним из вариантов общего подхода на основе парных перестановок характеризуется наилучшими вычислительными качествами среди исследованных в статье методов. Согласно известным исследованиям генетический алгоритм сходится заведомо не хуже метода Монте-Карло. Проведенное в статье исследование показывает, что метод штрафных функций в задаче размещения и для случая генетического алгоритма является малоэффективным. Поэтому представляет интерес в качестве особей популяции рассматривать перестановки без повторений. Это обстоятельство учитывается на этапах селекции и мутации: на указанных этапах стандартные вычисления согласно генетическому алгоритму дополняются процедурой парных перестановок генов в хромосоме.

В статье дано подробное описание программы для реализации на ЭВМ генетического метода.

Ключевые слова: электрическая схема, ограничения размещения, топологические параметры, метрические параметры, коммутационное поле, критерии и методы оптимизации.

\section{Литература}

I. Алгоритмы размещения элементов [Электронный ресурc]. https://helpiks.org/8-12562.html (дата обращения: 03.04.202I).

2. Николов Н.П. Размещение элементов электронных узлов методом многоуровневой декомпозиции и макромоделирования и реализация на его основе ППП для САПР РЭА. Дисс.. на соиск. уч. ст. канд. техн. наук по специальности 05.13.12. Львов. 1985.

3. Горбачев А.А. Методы и алгоритмы пространственной трассировки печатных плат. Дисс. на соиск. уч. ст. канд. техн. наук по специальности 05.13.12. Калининград. 1999.

4. Селютин В.А. Автоматизированное проектирование топологии БИС.М.: Радио и связь, 1983. 112 с.

5. Морозов К.К. Одиноков В.Г., Курейчик В.М. Автоматизированное проектирование конструкций радиоэлектронной аппаратуры. М.: Радио и связь, 1983. $278 \mathrm{c}$.

6. Мартюшев А.В. Метод плетей и границ в квадратичной задаче о назначениях: дисс. ... канд. физ.-мат. наук: 01.01.09. Санкт-Петербург, 2005. $100 \mathrm{c.}$

7. Палубецкис Г. С. Генератор тестовых задач квадратичного назначения с известным оптимальным решением// Ж. вычисл. матем. и матем. физ. T. 28. № II (I988), c. I740-I743.

8. Леушкин А.Д., Неймарк Е.А. Квадратичная задача о назначении. Обзор методов, генерация тестовых задач с априорно известным оптимумом // Труды НГТУ им. Р. Е. Алексеева. 2020. № 4 (І3І). с 26-35.

9. Старостин Н.В., Быкова Н.В. Многоуровневый алгоритм решения задачи архитектурно-зависимой декомпозиции. Учебно-методическое пособие. Нижний Новгород: Нижегородский госуниверситет, 2017. 24 с.

10. Рашковский С.А. Решение задач комбинаторной оптимизации методом Монте-Карло // Доклады Академии наук. 20I6. Т. 47І. № 4. С. $403-407$.

II. Rashkovskiy S.A. Monte Carlo solution of combinatorial optimization problems // Doklady Mathematics. 20I6. T. 94. № 3. C. $720-724$.

12. Дарховский Б. С., Попков А. Ю., Попков Ю. С. Метод пакетных итераций Монте-Карло для решения задач глобальной оптимизации // ИТиВС, 20I4, выпуск 3, 39-52.

13. Кулаков А.А. Разработка и исследование алгоритмов оптимального размещения компонентов СБИС трёхмерной интеграции. диссертации и автореферата по ВАК РФ 05.13.12, канд. техн. наук. 2016, Таганрог. С. 164.

Информация об авторе:

Абас Висам Махди Абас, аспирант Южно-Российского государственного политехнического университета (Новочеркасский политехнический институт), кафедра прикладной математики, Новочеркасск, Россия 